\title{
Peningkatan Kualitas Produk dan Minimasi Pemborosan Dengan Mengunakan Pendekatan Six Sigma Pada Perusahaan Pakan Ternak
}

\author{
Katon Muhammad ${ }^{1}$, Kukuh Winarso ${ }^{2}$, Ida Lumintu ${ }^{3}$ \\ Program Studi Teknik Industri, Fakultas Teknik, Universitas Jenderal Soedirman \\ ${ }^{1} \mathrm{Jl}$. Profesor DR. HR Boenyamin No.708, Purwokerto, Banyumas 53122 \\ Email: katon.muhammad@gmail.com \\ ${ }^{2,3}$ Program Studi Teknik Industri, Fakultas Teknik, Universitas Trunojoyo Madura \\ Jl. Raya Telang, Po-Box 2 Kamal, Bangkalan 69162 \\ Email: kukuh.winarso@trunojoyo.ac.id, ida.lumintu@gmail.com
}

\begin{abstract}
ABSTRAK
PT.XYZ adalah salah satu perusahan pakan ternak yang memiliki beberapa unit produksi terbesar yang ada di indonesia. Perusahaan pakan ternak ini memiliki beberapa merek produk yang beredar dipasaran. lini produksi perusahaan terindikasi memiliki permsalahan yaitu cacat produk. cacat produk yang diakibatkan oleh proses produksi dan juga proses penyimpanan bahan baku dan bahan jadi di perusahaan. Pendekatan six sigma yang didalamnya memiliki fase define, measure, analyze, improve dan control dipilih untuk menangulangi permasalahan yang ada. Dari fase define, measure dan analyze diketahui bahwa terdapat cacat yang signifikan yaitu cacat dengan atribut kutu pada proses produksi, tekstur, gumpalan dan kutu pada inventory. Dari hasil penilaian RPN diketahui bahwa cacat kutu pada lini produksi didapaatkan nilai sebesar 168, tekstur 105 dan kutu pada proses produksi 90 sehingga dari hasil penilaian RPN ini dilakukan untuk pemberian rekomendasi perbaikan dengan pertimbangan nilai RPN tertinggi. Rekomendasi perbaikan yang diusulkan adalah pemasangan blower dan juga alat pengatur temperatur udara pada bagian penyimpanan perusahaan, melakukan perancangan eksperimen secara bertahap untuk pemilihan bahan baku yang terbaik dengan mempertimbangkan permasalahan kualitas produk yang diproduksi dan yang ketiga ditingkatkannya jadwal cleaning pada bagian cooler, spoting dan juga rotex pada mesin produksi untuk meminimasi penyebab terjadinya cacat.
\end{abstract}

Kata kunci : Cacat Produk; Pakan Ternak; RPN; Six Sigma.

\section{ABSTRACT}

PT. XYZ is one of the animal feed companies which has some of the largest production units in Indonesia. This Feed Company has several brands of products on the market. The company's production line is indicated to have a problem, namely product defects. Defective products caused by the production process and also the process of storing raw materials and finished materials in the company. Related to the six sigma in it has a phase of define, measure, analyze, improve and control phases, is chosen to overcome the existing problems. From the define, measure and analyze phase, it is known that there are significant defects, namely defects with flea attributes in the production process, textures, lumps, and ticks in the inventory. From the results of the RPN assessment, it is known that tick defects on the production line are valued at 168, text 105 and ticks in the production process 90 so that from the results of the assessment the RPN is given recommendations for improvement with consideration of the highest RPN value. The recommended improvement recommendations are the installation of blowers and air temperature regulators in the company's storage section, conduct a design of experiment in stages to select the best raw materials by considering the quality problems of the products produced and thirdly, the improvement of the cleaning schedule in the cooler, spoting and also rotex on production machines to minimize the cause of defects.

Keywords : Product Defect; Animal Feed; RPN; Six Sigma

\section{Pendahuluan}

Kualitas merupakan salah satu jaminan yang harus diberikan oleh perusahaan terhadap pelanggan. Termasuk pada kualitas dari produk yang diproduksi, dikarenakan kualitas dari produk ini merupakan kriteria yang cukup penting digunakan pelanggan dalam menentukan produk yang akan digunakan. Selain itu pada sisi perusahaan, kualitas juga merupakan salah satu indikator yang penting untuk perusahaan dapat tetap bersaing di dalam persaingan pasar yang semakin ketat. Oleh sebab itu diperlukannya peningkatan kualitas oleh perusahaan dan juga 
memperbaikinya secara terus-menerus sesuai dengan kebutuhan yang dibutuhkan oleh pelanggan. Meburut Ratnadi (2020) salah satu aktivitas menciptakan kualitas agar dapat sesuai standar adalah dengan melakukan penerapan sistem pengendalian kualitas yang tepat, memiliki tujuan dan tahapan yang jelas, serta memberikan inovasi dalam melakukan pencegahan dan penyelesaian permasalahan kualitas yang ada.

PT XYZ merupakan salah satu perusahan pakan ternak terbesar yang ada di indonesia, dimana perusahaan ini memproduksi beberapa macam produk pakan unggas. utuk memenuhi kebutuhan pasar. Perusahaan ini harus bersaing dengan dengan kompetitor atau perusahaan lain yang memproduksi produk yang sejenis. Oleh karena itu, perusahaan harus meningkatkan kualitas dan mutu produk sendiri agar lebih optimal untuk memenuhi permintaan pasar. Selain itu juga perusahaan menghadapi berbagaimacam tantangan mulai dari persaingan dari kompetitor perusahaan lain hingga permasalahan yang ada pada lini produksi didalam perusahaan itu sendiri, diantaranya yaitu defect produk dan juga beberapa permasalahan pada lini inventory yang mengakibatkan munculnya permasalahan yang ada didalam perusahaan.

Apabila permasalahan defect produk dan juga inventory yang mengakibatkan perusahaan ini tidak ditanggulangi dengan baik maka akan berakibat pada penurunan kualitas produk dan juga efisiensi perusahaan sehingga berimbas pada penurunan profit yang didapatkan oleh perusahaan nantinya. Dari permasalahn yang ada perusahaan sebaiknya harus mengoptimalkan semua sumberdaya yang dimiliki sehingga produktivitas perusahaan semakin baik dan dapat berdampak pada lini produksi yang semakin efisien sehingga perusahaan dapat tetap bersaing didalam persaingan bisnis yang ada. Pendekatan konsep Pendekatan konsep DMAI (Define Measure Analyze Improve) dirasa sangat efektif untuk mengatasi permasalahan efisiensi dan juga permasalahan kualitas yang sering terjadi pada perusahaan. Pendekatan ini disebut juga dengan six sigma. Menurut Gaspesz (2008) Six sigma adalah suatu upada terus-menerus untuk menurunkan variasi dari proses agar dapat meningkatkan kapabilitas proses dalam menghasilkan produk yang bebas dari defect ataupun kesalahan. pada Proses produksi yang memperhatikan kualitas akan menghasilkan produk yang bebas dari kerusakan. Hal ini dapat menghindarkan perusahaan dari pemborosan sehingga biaya produksi dapat ditekan dan harga produk dapat menjadi lebih kompetitif (Windarti, 2014)

Terdapat beberapa tujuan yang ingin dicapai pada penelitian ini, diantaranya yaitu : Mengetahui waste yang paring berpengaruh pada perusahaan. Mengetahui critacal to quality pada waste yang berpengaruh. Mengukur tingkat sigma pada proses produksi perusahaan. Mengidentifikasi penyebab waste yang paling berpengaruh pada perusahaan dan merancang usulan perbaikan untuk meminimasi waste yang paling berpengaruh pada perusahaan.

\section{Metode Penelitian}

Menurut Fithri (2019) asal kata sigma berasal dari abjad yunani yang menunjukan standar deviasi atau persebaran rata-rata proses. Nilai sigma juga dapat diartikan sebagai tingkat keseringan cacat yang mungkin terjadi. Semakin tinggi tingkat sigma maka semakin rendah pula toleransi yang diberikan pada suatu kecacatan produk sehingga kapabilitas proses dalam suatu sistem menjadi semakin tinggi.

Six sigma memiliki tujuan untuk membuat suatu performansi bisnis tanpa adanya kesalahan. Six sigma memiliki standar yang besarnya 3,4 permasalahan dalam satu juta kali kesempatan atau yang biasa disebut defects per million opportunities (DPMO) (Pyzdek, 2002)

Menurut Thomas et al (2009) Didalam six sigma terdapat lima fase yang digunakan dalam menanggulangi permasalahan yang ada secara komprehensif. Langkah-langkah sebagai berikut:

1. Define, berhubungan dengan konsumen, prioritas konsumen, permasalahan yang ada hingga mencari solusi

2. Measure, didalamnya dilakukan pengukuran terhadap performansi dari suatu proses

3. Analyze, didalamnya dilakukan analisa akar penyebab dari suatu permasalahan.

4. Improve, pembuatan desain ulang atau perbaikan terhadap proses dan melakukan pengujian.

5. Control, melakukan suatu pengendalian terhadap pengembangan yang dilakuakan.

\section{Define}

Pada tahap define yang dilakukan adalah :

1. Pada tahap awal ini melakukan penggambaran kondisi lapangan yang akan menjadi objek penelitian menggunakan tool Value Stream Mapping dengan cara menggambarkan aliran informasi mulai dari awal hingga akhir atau dari hulu hingga ke hilir. Proses tersebut dimulai dari datangnya pemesanan dari konsumen hingga produk akhir jadi dan aliran material proses produksi.

2. Melakukan identifikasi jenis-jenis waste EDOWNTIME yang terjadi pada proses produksi di PT XYZ berdasarkan hasil pengamatan yang dilakukan di lapangan. 


\section{Meassure}

Pada tahap measure yang dilakukan adalah :

1. Mengidentifikasi waste yang paling berpengaruh terhadap kualitas proses produksi PT XYZ berdasarkan definisi waste E-DOWN TIME yang diperoleh dari hasil wawancara kuisioner, pengamatan di lapangan, dan data historis perusahaan yang berkaitan dengan waste.

2. Menentukan Critical To Quality (CTQ) pada proses produksi PT XYZ berdasarkan hasil waste yang paling berpengaruh dengan menggunakan pareto chart.

3. Mengukur kapabilitas proses produksi untuk mengetahui nilai sigma perusahaan saat ini.

\section{Analyze}

Pada tahap analyze ada bebrapa tahap yang dilakukan diantaranya :

1. Menganalisis waste yang paling berpengaruh dengan Root Cause Analysis untuk mengetahui faktor-faktor penyebab kritis dari terjadinya waste.

2. Melakukan pengukuran nilai SOD atau Saverity, Occurance, Detection diaman Saverity mrupakan tingkat keseringan effect yang digunakan dari kegagalan yang terjadi, Occurance merupakan probabilitas frekuensi kegagalan yang terjadi, Detection merupakan kemampuan dari proses control dalam mendeteksi metode kegagalan (failure mode) yang mengakibatkan terjadinya kegagalan.

3. Melakukan analisis dari hasil RPN atau Risk Priority Number dari perhitungan metode Failure Mode and Effect Analysis (FMEA) dari wawancara dengan orang yang berkompeten, sehingga nantinya didapatkan nilai waste dengan niali RPN yang terbesar akan dijadikan prioritas utama untuk dilakukan perbaikan.

\section{Improve}

Pada tahap improve yang dilakukan anataralain :

1. Memeberikan usulan perbaikan berdasarkan faktor-faktor penyebab kritis yang dapat dilihat dari nilai RPN tertinggi.

2. Memberikan rancangan strategi peningkatan kualitas yang dapat diterapkan oleh perusahaan

\section{Hasil dan Pembahasan}

Pada tahap awal yaitu identifikasi pemborosan pada perusahaan dimana sesuai yang dikemukakan gaspersz (2007) terdapat 9 macam pemborosan yang biyasa disingkat EDOWTIME. Diantaranya yaitu Environmental, Health and Safety. Defect, over production, Waiting, Not Utilizing Employes Untuk menentukan critical to quality dari defect yang dipengaruhi oleh proses produksi maka dilakukan perhitungan dengan mengunakan pareto knowladge, Skill and Abilities, Transportation, Inventory, Motion, Excess Processing.

\section{Menentukan Waste Paling Berpengaruh}

Dari hasil pengamatan pada perusahaan, data historis yang berhubungan dengan sembilan macam pemborosan yang ada pada perusahaan tidak dicatat dengan lengkap, hanya sebagian data yang dirasa paling signifikan mempengaruhi kinerja perusahaan yang didokumentasikan. sehingga dengan adanya dokumentasi yang tidak lengkap pada perusahaan maka pada penelitian ini dilakukan melalui interview pada pihak perusahaan. Dari hasil interview diperoleh bahwa waste yang paling signifikan adalah waste defect yang dipengaruhi oleh proses produksi dan juga defect yang dipengaruhi oleh proses inventory yang telah didokumentasikan oleh perusahaan dengan baik. Sehingga defect tersebut menjadi fokus utama pada penelitian.

\section{Menentukan Critical To Quality}

Critical To Quality merupakan aribut atau karakteristik yang memilki pengaruh terhadap kualitas produk. Menurut Gaspersz (2002) Critical to Quality sendiri adalah atribut-atribut yang berkaitan langsung dengan kebutuhan pelanggan dan sangat penting untuk diperhatikan. Dimana CTQ ini merupakan elemen-elemen dari suatu produk, proses atau praktik-praktik yang berkaitan dengan dan berdampak langsung pada kepuasan pelanggan. Jenins-jenis kegagalan pada produk bisa dijadikan sebagai karakteristik kualitas kunci pada produk tersebut. Untuk dapat mengetahui Critical To Quality diperlukan identifikasi yang disesuaikan dengan waste atau pemborosan yang memiliki pengaruh yang siknifikan

1. Critical To Quality Waste Defect Yang Dipengaruhi Oleh Proses Produksi

Dapat diketahui atribut defect yang dapat menyebabkan waste defect dapat dikategorikan ada beberapa macam jenis defect yang terdapat pada perusahaan diantaranya yaitu kontaminasi, tekstur, temperatur, bau, warna, gumpalan, benda asing dan juga kutu. Berikut dapat dilihat data jenis defect yang tercantum pada tabel 1 .

Tabel 1. Data jenis defect produksi

\begin{tabular}{lcccccccc}
\hline jenis defect kontaminasi temperatur & bau & warna & tekstur & kutu & gumpalan benda asing \\
\hline defect $(\mathrm{kg})$ & 300 & 900 & 400 & 600 & 6100 & 7800 & 5800 & 400 \\
prosentase & $1.35 \%$ & $4.04 \%$ & $1.79 \%$ & $2.60 \%$ & $27.35 \%$ & $34.98 \%$ & $26.01 \%$ & $1.79 \%$ \\
\hline
\end{tabular}


Berikut merupan penentuan CTQ dengan mengunakan pareto diagram

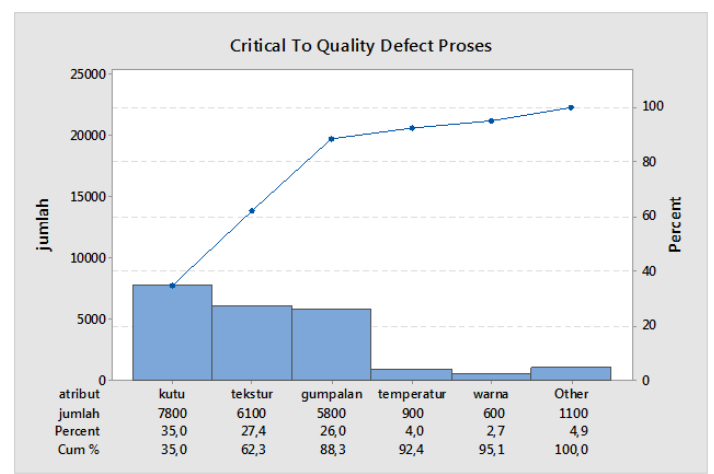

Gambar 1. Pareto chart jumlah defect yang dipengaruhi oleh proses produksi

Berdasarkan gambar pareto chart diatas dapat diketahui atribut kritis dari defect yang disebabkan oleh proses produksi yaitu diantaranya kutu, tekstur dan juga gumpalan. Dengan prosesntase kutu sebesar $34,9 \%$, tekstur $27,35 \%$ dan gumpalan 26,01\%. Dari hasil ini defect kutu, tekstur dan gumpalan merupakan CTQ dari defect yang dipengaruhi oleh proses produksi.

\section{Critical To Quality Waste Defect Yang}

Dipengaruhi Oleh Proses Penyimpanan

Untuk mencari critical to quality defect pada proses penyimpanan di perusahaan maka dilakukan perhitungan dengan mengunakan pareto diagram. Data yang digunakan merupakan data defect pada proses penyimpanan dengan rentang data beberapa periode. Hasil perhitungannya dapat dilihat pada gambar 2 berikut ini.

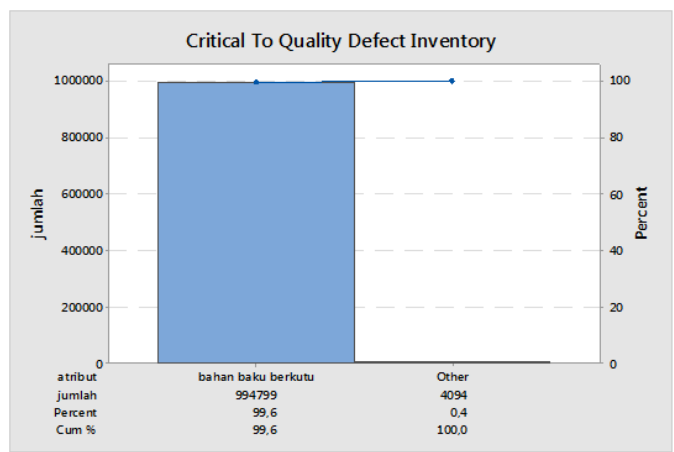

Gambar 2. Jenis defect yang dipengaruhi oleh proses inventory

Dari hasil pareto diagram yang dapat dilihat pada gambar 2 berikut ini. Dapat diketahui atribut defect paling kritis yaitu bahan baku berkutu yaitu sebesar 99,6 \% dimana bahan baku berkutu ini memiliki persentase yang cukup tinggi dibandingkan dengan atribut yang lainnya.

\section{Mengukur Tingkat Sigma Perusahaan}

Defect yang terjadi pada proses produksi perusahaan menunjukan tingkat sigma yang kurang baik. Dapat dilihat dari tingkat sigma yang diukur menunjukan fluktuasi dan masih belum stabil di tingkat sigma yang tinggi. berikut merupakan data tingkat sigma yang didapat dari data defect yang didapatkan dari proses produksi dan juga tingkat sigma yang didapat dari proses inventory perusahaan

\section{Tingkat Sigma Pada Proses produksi.}

Berikut merupakan perhitungan tingkat sigma yang dihitung dari rentang beberapa periode dimana pada setiap periode mengunakan data defect produk yang dikalkulasikan tiap bulan pada produk yang berada pada proses produksi. Hasil perhitungan tingkat sigma dapat dilihat pada gambar 3 berikut ini.

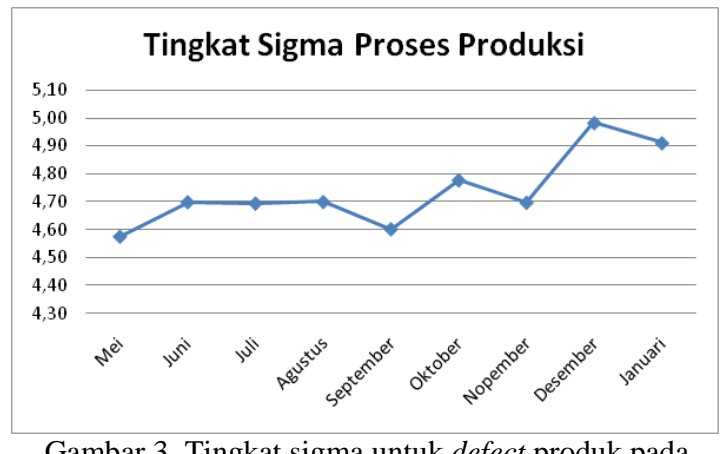

Gambar 3. Tingkat sigma untuk defect produk pada proses produks

Dari gambar tersebut dapat diketahui bahwa pada periode data di bulan mei hingga bulan agustus tingkat sigma meningkat, akan tetapi pada bulan september hingga januari fluktuatif terdapat kenaikan dan penurunan. Pada defect ini memiliki tingkat sigma di kisaran 4,57 hingga 4,98 yang nenunjukkan tingkat sigma sudah baik namun masih perlu adanya peningkatan.

\section{Tingkat Sigma Pada Lini Inventory}

Berikut merupakan perhitungan tingkat sigma yang dihitung dari rentang beberapa periode dimana pada setiap periode mengunakan data defect produk yang dikalkulasikan tiap bulan pada produk yang berada pada lini inventory. Hasil perhitungan tingkat sigma dapat dilihat pada gambar 4 berikut ini. 


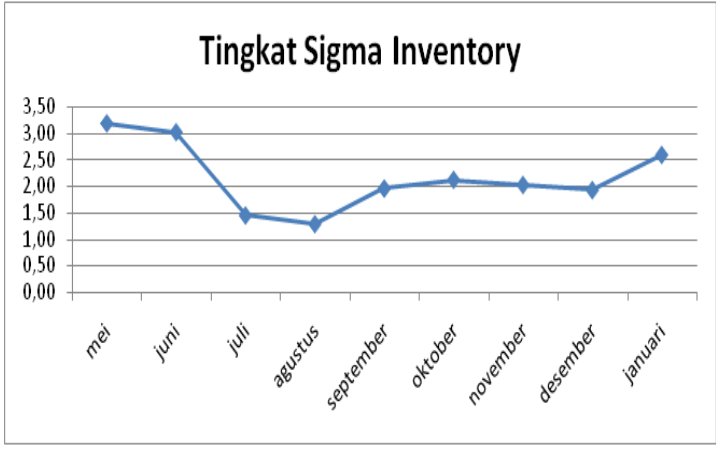

Gambar 4. Tingkat sigma untuk defect produk pada lini inventory

Dari grafik tingkat sigma diatas dapat diketahui bahwa tingkat sigma fluktuatif berkisar anatara 1,28 hingga 3,13 yang menunjukkan bahwa lini inventory bahan baku produksi pada perusahaan masih buruk dan memerlukan perbaikan yang signifikan.

\section{Menganalisis Defect Produk Paling Signifikan}

Menganalisis defect produk ini digunakan untuk dapat mengetahui akar dari penyebab defect sehingga dapat dilakukan proses improvement nantinya. Dalam pelaksanaan analisi ini akan mengunakan Root Cause Analisys. Menurut Jucan (2005) Root Cause Analisis merupakan suatu metode yang dapat digunakan untuk mengidentifikasi dan juga mengoreksi sebab-sebab yang penting dalam permasalahan operasional dan fungsional. Root Cause Analisis digunakan untuk tujuan mengetahui penyebab masalah yang ada atau kejadian dengan cara mengidentifikasi akar-akar penyebab masalah tersebut.

1. Root Cause Analysis Waste Defect Yang Disebabkan Oleh Proses Produksi. Root cause analysis defect kutu

Pada gambar root cause analysis defect di Gambar 6 dapat diketahui bahwa defect kutu pada proses produksi dipengaruhi oleh beberapa faktor yaitu bahan baku terkontaminasi kutu yang disebabkan oleh umur penyimpanan bahan baku yang melebihi batas dan juga fumigasi dari produk berkutu yang tidak serentak. Sedangkan pada faktor lain yaitu sarang kutu pada bagian mesin dipengaruhi oleh pecahan produk berupa partikel halus pada beberapa bagianmesin.

Pada defect gumpalan dapat diketahui penyebab utama yaitu kinerja mesin yang kurang maksimal yang disesbabkan oleh tekanan mesin press kurang dan juga temperatur mesin press kurang. Selain itu juga kadar air yang tidak sesuai yang diakibatkan oleh steam uap yang trobel merupakan faktor penyebab defect gumpalan.

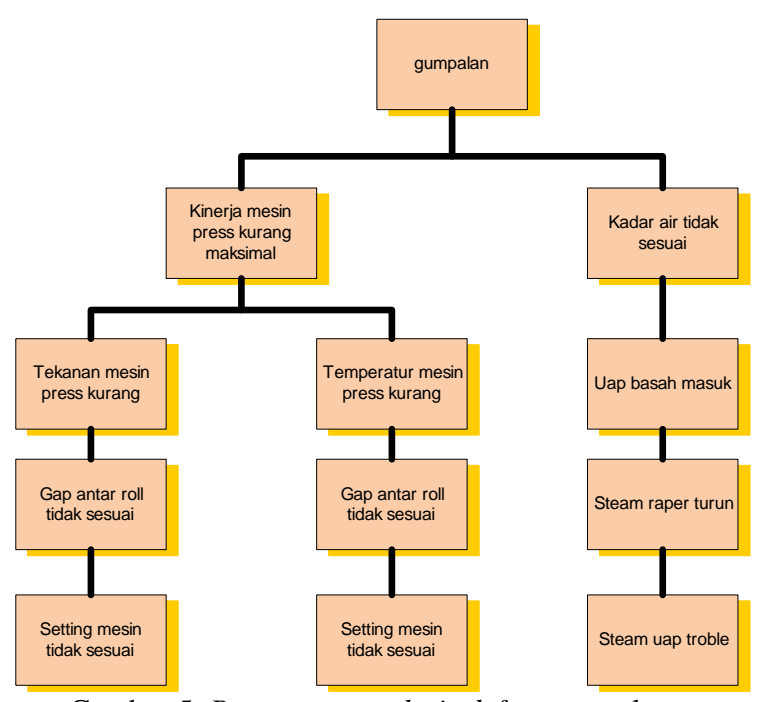

Gambar 5. Root cause analysis defect gumpalan

Selain itu juga terdapat defect tekstur yang disebabkanoleh proses produksi dari hasil root cause analysis defect tekstur diketahui beberapa faktor defect tekstur ini diantaranya yaitu proses ayak yang tidak maksimal dan juga durability produk rendah. Proses ayak tidak maksimal dipengaruhi oleh mesin rotex yang troble dan juga fider speed idak sesuai. Sedangkan durability produk dipengaruhi oleh steam pada proses pelleting yang tidak optimal, karakkteristik bahan baku digunakan, gap antar roll dan matras, roll dan matras aus, proses glatinisasi tidak sesuai dan juga pisau potong pada proses pelleting tidak sesuai.

2. Root Cause Analysis Waste Defect Yang Disebabkan Oleh Proses Inventory

Dari hasil analisis dan juga wawancara kepada pihak perusahaan terdapat beberapa penyebab utama defect produk berupa kutu pada lini inventory. Berikut merupakan Root Cause Analysis dari defect kutu pada bahan baku di lini inventory. Root Cause Analysis defect kutu pada lini inventory dapat dilihat pada Gambar 7. Dari gambar 7 dapat dilihat pada defect kutu pada lini inventory ini dipengaruhi oleh beberapa faktor diataranya yaitu pacaroba musim, penyimanan pada gudang kurang bersih, ruang gudang lembap, penyimpanan di bagian silo terkontaminasi kutu, dan bahan baku usang.

Pengukuran Nilai Severity, Occurance dan Detection

Untuk dapat menganalisis penentuan prioritas dari sebuah kegagalan maka diperlukan pendefinisian nilai severity, occurance, dan juga detection yang digunakan untuk dapat melakukan perhitungan nilai Risk Priority Number dari metode FMEA ini. menurut Hariastuti (2015) dengan mengunakan metode Failure Mode and Effect 
Analysis faktor-faktor penyebab dominan terjadinya defect produk akan diketahui dengan melihat nilai Risk Priority Number (RPN) yang didapat dari analisis FMEA, sehingga rekomendasi perbaikan dapat diberikan secara tepat. Tabel perhitungan FMEA keseluruhan waste dapat dilihat pada Tabel 2

Dari hasil Failure Mode And Effect Analysis pada perhitungan Risk Priority Number didapatkan hasil RPN yang mana hasil dari menilaian Risk Priority Number ini digunakan untuk memprioritaskan rekomendasi perbaikan yang akan diimplementasikan diperusahaan. Dari hasil perhitungan FMEA didapatkan nilai RPN tertinggi yaitu permasalahan pada temperatur ruangan penyimpanan dengan nilai Risk Priority Number sebesar 168, pemilihan jenis bahan baku kurang sesuai dengan nilai Risk Priority Number sebesar 105, pecahan produk dari proses grinder dan rotex dengan nilai Risk Priority Number sebesar 90. Hal ini menunjukan bahwa tiga akar permasalahan ini merupakan akar permasalahan yang paling kritis untuk dilakukan improvement agar defect produk dapat ditangulangi secara signifikan.

\section{Rekomendasi Perbaikan}

Dari perhitungan risk priority number pada metode failure mode and effect anaysis diketahui defect dengan nilai RPN tertinggi hingga terendah. Penilaian RPN ini digunakan untuk priorotas penanggulangan nantinya. Berikut merupakan rokomendasi untuk meminimasi dan juga mencegah terjadinya defect produk dengan tujuan meningkatkan kualitas dari produk yang diproduksi perusahaan. Usulan perbaikan itu diantaranya:

1. Usulan perbaikan pada defect kutu yang disebabkan oleh proses penyimpanan diantaranya yaitu penambahan alat pengatur suhu ruangan dan juga blower yang digunakan untuk mengontrol suhu ruangan pada lini penyimpanan produk bahan baku di perusahaan. penerapan firs in firs out pada gudang bahan baku untuk meminialisir terdapatnya produk usang pada gudang. Selanjutnya yaitu penyediaan penutup produk untuk menutupi bahan baku curah yang ditempatkan pada gudang bahan baku agar meminimalisir bahan baku curah dapat terkontaminasi kutu.

2. Usulan perbaikan pada defect tekstur yaitu melakukan perancangan eksperimen secara bertahap untuk pemilihan bahan baku yang terbaik dengan mempertimbangkan permasalahan kualitas produk yang diproduksi nantinya. Selanjutnya Pembuatan scedule preventive maintenance untuk meminimasi rasio kerusakan pada mesin ayakan. Yang ketiga yaitu pembuatan SOP beberapa mesin produksi diantaranya yaitu SOP setting feeder speed pada mesin rotex, setting steam pada steam pelleting, setting pisau potong dan juga setting gap matras terhadap roll pada proses pelleting.

3. Pada defect kutu pada proses produksi yaitu ditingkatkannya jadwal cleaning pada bagian cooler, spoting dan juga rotex pada mesin produksi dikarenakan pada bagian ini kutu seringkali bersarang dan berkembang biak. Yang kedua yaitu pencegahan secara preventive dan juga pembuatan jadwal fuigasi terhadap produk yang terkontaminasi kutu.

4. pada defect gumpalan terdapat beberapa usulan perbaikan diantaranya melakukan pemanasan mesin press terlebih dahulu sebelum digunakan hingga temperatur dan juga tekanan mesin cukup, sehigga mesin dapat bekerja secara maksimal dan siap digunakan pada saat mesin sudah cukup lama dalam kondisi dingin akibat mesin dimatikan pada saat proses berhenti. Yang kedua yaitu dibutuhkan scedule preventive maintenance pada steam uap untuk meminimasi rasio kerusakan yang terjadi.

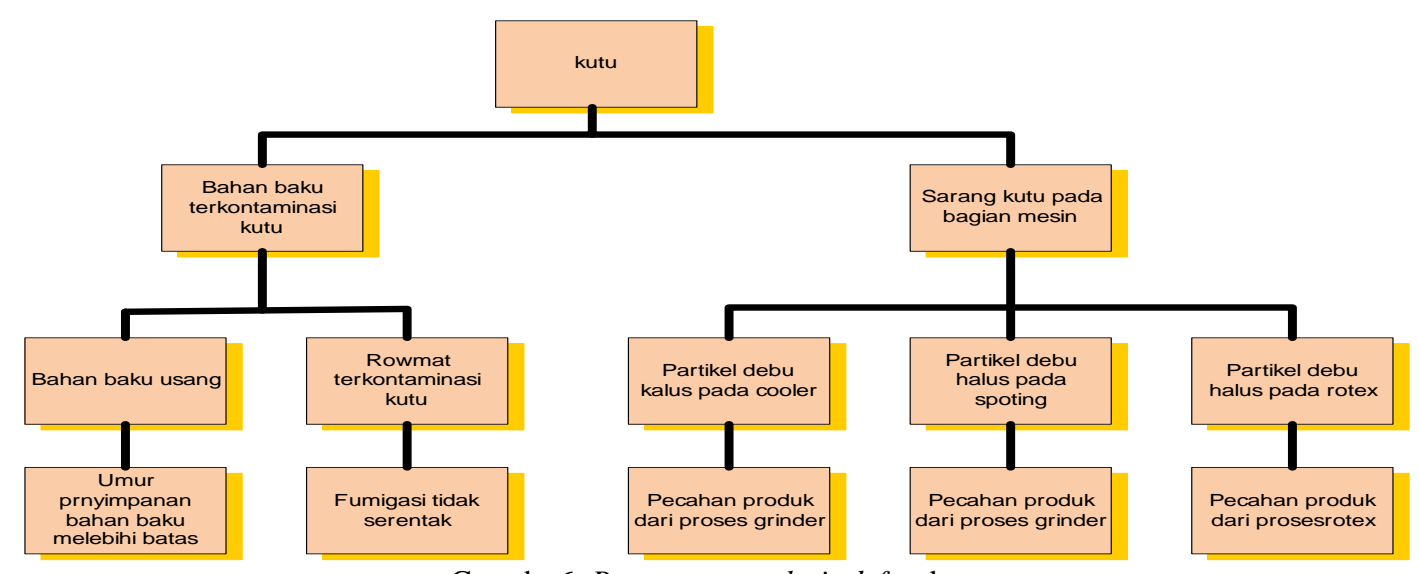

Gamabr 6. Root cause analysis defect kutu 


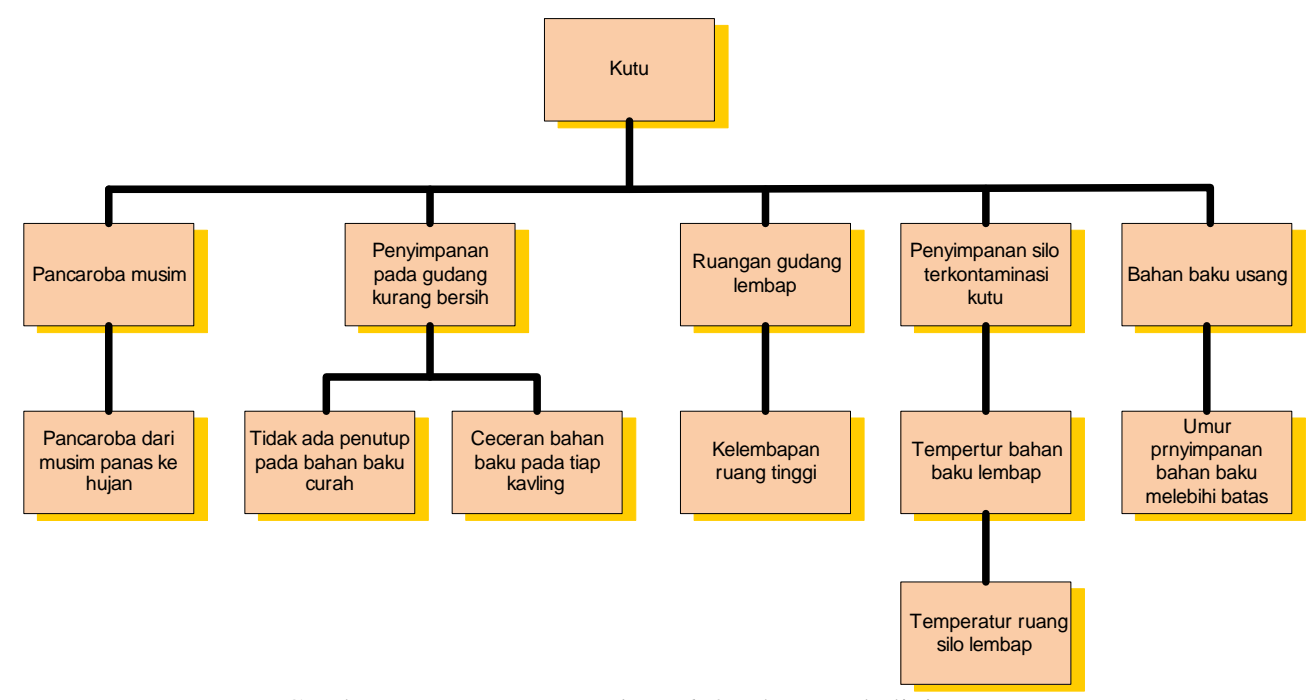

Gambar 7. Root cause analysis defect kutu pada lini inventory

Tabel 2. Failure Mode Effect Analysis Keseluruhan Waste

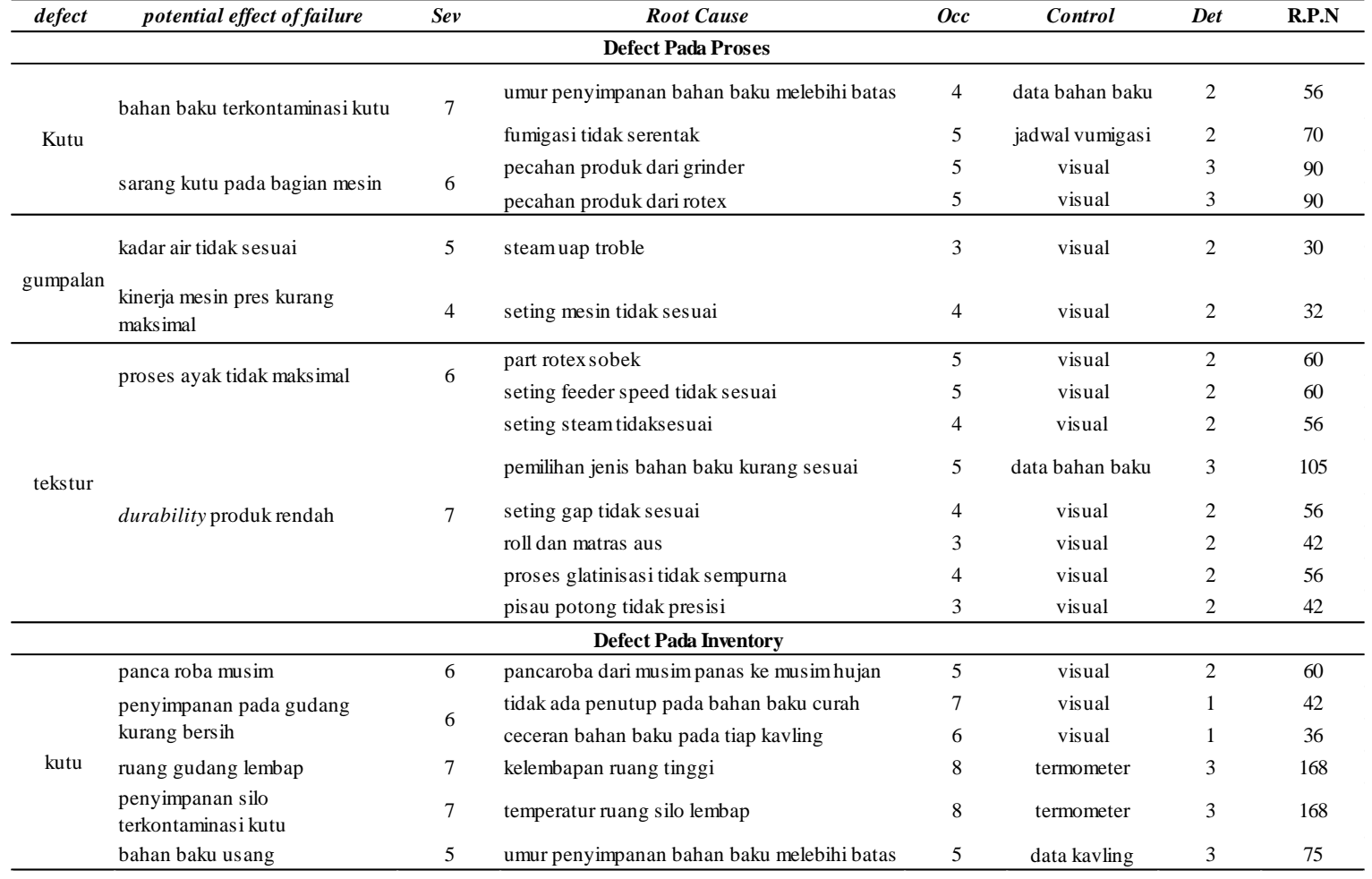

\section{Kesimpulan}

1. Dari hasil analisis dan juga pengamatan pada perusahaan pada tahap define dapat diketahui jenis waste yang memiliki pengaruh cukup tinggi pada proses produksi PT XYZ yaitu waste defect yang dipengaruhi oleh proses produksi dan juga defect yang diakibatkan oleh proses inventory.

2. Hasil identifikasi Critical To Quality pada defect yang terjadi dengan menggunakan pareto chart yaitu defect kutu sebesar $36,5 \%$, defect tekstur sebesar 26,7\%, defect gumpalan sebesar $25,4 \%$.sedangkan pada lini inventory defect "kutu pada bahan baku produksi" sebesar 99,6 $\%$.

3. Hasil pengukuran kapabilitas proses untuk waste defect yang disebabkan oleh proses produksi perusahaan yang dinyatakan dengan tingkat sigma memiliki niali 4,58-4,98 pada defect yang disebabkan oleh proses produksi. Sedangan tingkat sigma pada defect di inventory sberkisar 1,28-3,18.

4. Dari hasil Failure Mode And Effect Analysis pada perhitungan Risk Priority Number 
didapatkan hasil RPN tertinggi beruntun diantaranya yaitu permasalahan pada temperatur ruangan penyimpanan dengan nilai RPN 168, pemilihan jenis bahan baku kurang sesuai (kualitas rendah) dengan nilai RPN 105 dan pecahan produk dari proses grinder dan rotex dengan nilai RPN 90. Hasil dari penilaian RPN ini digunakan untuk pemprioritasan rekomendasi perbaikan yang akan diimplementasikan pada perusahaan.

5. Terdapat beberapa usulan perbaikan yang didaptkan dari penilaian Risk Priority Number tertinggi yang pertama yaitu pemasangan blower dan juga alat pengatur temperatur udara pada bagian penyimpanan perusahaan. Yang kedua yaitu melakukan perancangan eksperimen secara bertahap untuk pemilihan bahan baku yang terbaik dengan mempertimbangkan permasalahan kualitas produk yang diproduksi nantinya. Yang ketiga yaitu ditingkatkannya jadwal cleaning pada bagian cooler, spoting dan juga rotex pada mesin produksi untuk meminimasi pentebab terjadinya defect kutu pada proses akibat terdapat sarang kutu pada bagian mesin produksi.

\section{Daftar Pustaka}

Fithri, P. (2019) Six Sigma Sebagai Alat Pengendalian Mutu Pada Hasil Produksi Kain Mentah PT Unitex, Tbk. J@ ti Undip: Jurnal Teknik Industri, 1(1), 4252.

Gaspersz, Vincent. (2007) Lean Six Sigma for Manufacturing and Service Industries, Jakarta: Gramedia Pustaka Utama

Gaspersz, Vincent. (2002) Pedoman Implementasi Program Six Sigma Terintegrasi dengan ISO 9001:2000, MBNQA, dan HACCP. Jakarta: Gramedia Pustaka Utama.

Gaspersz, Vincent. (2008) The Executive Guide To Implementing Lean Six Sigma, Jakarta: Gramedia Pustaka Utama

Hariastuti, N. L. P. (2015). Analisis pengendalian mutu produk guna meminimalisasi produk cacat.

Jucan, G. (2005). Root cause analysis for IT incidents investigation. Toronto, Ontario.

Pyzdek, T. (2002) The Six Sigma Hand Book. Jakarta : Salemba Empat

Ratnadi, R., \& Suprianto, E. (2020). Pengendalian Kualitas Produksi Menggunakan Alat Bantu Statistik (Seven Tools) Dalam Upaya Menekan Tingkat Kerusakan Produk. Jurnal Industri Elektro dan Penerbangan, 6(2)

Thomas, A., Barton, R., \& Chuke-Okafor, C. (2009). Applying lean six sigma in a small engineering company-a model for change. Journal of Manufacturing Technology Management.

Windarti, T. (2014). Pengendalian kualitas untuk meminimasi produk cacat pada proses produksi besi beton.J@ Ti Undip: Jurnal Teknik Industri, 9(3), 173-180. 